\title{
Maternal Knowledge and Practices Towards Sanitation and Their Relationships with Occurrence of Diarrhoea in Children
}

\author{
Shriya A. Seksaria, Mini K. Sheth \\ Department of Foods and Nutrition, Faculty of Family and Community Sciences, The Maharaja Sayajirao University of \\ Baroda, Vadodara, Gujarat, INDIA
}

\begin{tabular}{l} 
Article Info \\
\hline Article history: \\
Received May 08, 2014 \\
Revised July 20, 2014 \\
Accepted Aug 27, 2014
\end{tabular}

Keyword:

Childhood diarrhea

Tribal mothers

Hygiene and sanitation

\begin{abstract}
Diarrhoea, a major contributor of childhood morbidity and mortality is mostly caused by poor hygiene and sanitation. Literature reveal that hygiene practices at household levels greatly affects the occurrence of diarrhoea among children. A cross sectional study was conducted to determine association between hygiene knowledge and practices of mothers with occurrence of diarrhoea in young children below 3 years in the tribal villages of Gujarat. Structured questionnaire was used to elicit information on personal hygiene $(\mathrm{PH})$, food Hygiene (FH), and environmental Hygiene (EH) practices of 536 mothers with children between 6-36 months of age. Past one month diarrhoeal episodes were recorded using the recall method. The mean percent scores for $\mathrm{FH}, \mathrm{PH}$ and $\mathrm{EH}$ practices were $77 \%, 88 \%$ and $80 \%$ respectively. Almost $35 \%$ children suffered from diarrhoea in the past one month of which 10 were admitted to the hospital. Diarrhoeal incidences were associated with $\mathrm{FH}$ and $\mathrm{EH}$ practices $(\mathrm{p}<0.001)$ and not with $\mathrm{PH}$ practices. Improvement in the environmental and personal hygiene practices of the mothers can contribute largely in reducing the prevalence of diarrhoea among children in Chikhli taluka of Gujarat.
\end{abstract}

Copyright (C) 2014 Institute of Advanced Engineering and Science. All rights reserved.

Corresponding Author:

Shriya A. Seksaria,

Department of Foods and Nutrition, Faculty of Family and Community Sciences,

The Maharaja Sayajirao University of Baroda,

Vadodara, Gujarat, INDIA

Email: shriya.seksaria@gmail.com

\section{INTRODUCTION}

An estimated 801,000 children younger than 5 years of age perish from diarrhea each year, mostly in developing countries. This amounts to $11 \%$ of the 7.6 million deaths of children under the age of five and means that about 2,200 children are dying every day as a result of diarrheal diseases [1]. Reducing diarrheal deaths by more than 1.4 million per year would be a major contribution towards MDG4 [2].

Diarrhoea targets mostly the poor community due to poor environmental sanitation, inadequate water supply, poverty and poor education [3]. As per WHO 2008 [4] estimates $81 \%$ cases of diarrhoea worldwide are attributable to unsafe water, inadequate sanitation or insufficient hygiene. These cases result in 1.5 million deaths each year, most being the deaths of children. In addition the total number of deaths caused directly and indirectly by malnutrition induced by unsafe water, inadequate sanitation and insufficient hygiene is 860000 deaths per year in children under five years of age. Globally, around 2.4 million deaths (4.2\% of all deaths) could be prevented annually if everyone practised appropriate hygiene and had good, reliable sanitation and drinking water [5]. According to estimations, $88 \%$ of all diarrhoeal diseases are caused due to contaminated water and inadequate hygiene and sanitation [6]. Other researchers also pointed out that 
that among the main childhood diseases that are directly linked to poor hygiene and sanitation is diarrhea [7][10].

World Health Organisation [11] has outlined the basic principles for the preparation of safe food for infants and young children but the effect of food-hygiene practices of mothers on diarrhoea among children in community settings has been sparingly reported [12],[13]. Moreover the tribal areas of Indian subcontinent are unexplored in this area.

Hence the study was undertaken with an objective to determine if the hygiene and sanitation knowledge and practices of mothers are associated with occurrence of diarrhoea in children. The study will help highlight the undesirable practices followed by the mothers with respect to domestic hygiene which might contribute to occurrence of diarrhoea in children.

\section{RESEARCH METHOD}

\section{Locale of study}

The study was carried out in the tribal villages of Chikhli taluka, Navsari District of Gujarat, India. Gujarat has 33 districts and Navsari district comprises of 6 talukas which includes 389 urban, rural and tribal villages. Chikhli a tribal taluka of Navasri district has 88 villages [14]. As reported Chikhli has a population of 293014, with 148,729 males and 144,285 females [15],[16].

Under the Integrated Child Development Scheme (ICDS) of Government of India, Chikhli taluka has about 400 functional anganwadis (community centre). Taking an average of 10 children between the age group 6- 36 months enrolled in each anganwadi, it was assumed that there are approximately 4000 children between 6-36 months in Chikhli. With a confidence interval of 4 and confidence level of $95 \%$ the minimum sample size calculates to be 522 . Therefore a sample of 536 was selected for the study.

\section{Sampling}

A map of Chikhli tuluka was taken and with Chikhli village as the center point a circle of $15 \mathrm{~cm}$ was drawn. The area was divided into 4 zones. Four villages were randomly selected from each zone and including Chikhli, a total of 17 villages were identified. About 31 households with children between 6-36 months were selected randomly from each village.

\section{Collection of data}

Data were collected by a trained investigator using a pretested proforma. The institutional ethical committee gave approval to the data schedule. Informed consent was taken from the mothers and they were explained the purpose of the study.

The questionnaire consisted of different sections to elicit information under the following heads i).background information to assess the socio economic status of the family; ii) household information iii) disease profile of the child for the past one month with reference to RTI and diarrhoeal episodes iv) knowledge and practices of mothers on hygiene and sanitation.

Background information was collected which included questions related to income of the family, educational qualification of mother and father, ownership of property, etc. This information was used to assess the socio economic status of the family according to criteria developed by Agrawal et al [17].

The hygiene and sanitation questionnaire included several close ended questions related to environmental, food and personal hygiene which helped assess the present knowledge and practices of the mothers in relation to the three hygiene aspects. The questionnaire was compiled as per the checklists developed and used by many investigators and government surveys [18]-[26]. The questionnaire was pretested with 15 mothers and modified accordingly. Each desirable response was given a score of 2 or 3 (depending on the question) and an undesirable response was given a score of 1. A composite score was calculated for each aspect and the mothers were ranked into four categories i.e excellent (with a score of 91$100 \%)$, very good $(76-90 \%)$, fair $(61-75 \%)$ and poor $(\leq 60 \%)$.

The questionnaire was developed in English but was translated to the local language (Gujarati) during administration. The investigator took about 20-30 minutes to administer one questionnaire.

\section{Statistical analysis}

Means and standard deviations for various responses were calculated using Microsoft Excel 2007. Epi Info software (Version 2000) was used to obtain association of diarrhoeal disease in children with various factors like child's age, SES, mothers' education, household facilities etc. p - Values smaller than 0.05 were considered to be statistically significant. 


\section{RESULTS AND ANALYSIS}

\section{Socio-demographic characteristics of respondents}

Out the 536 children enrolled most $(255 ; 47.6 \%)$ were in the age group of $13-24$ months, 153 were aged between 6-12 months and rest were between 25-36 months. The enrolled subjects had almost equal percentage of males and females. Majority of the families $(473 ; 88.2 \%)$ were Hindus and $50 \%$ of the children were the first offspring of their parents (Table 1).

Table 1. Background information of the child/ family

\begin{tabular}{|c|c|c|c|c|}
\hline 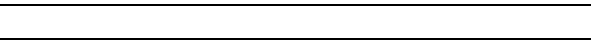 & Total & No. & $\%$ & Chi Square Value \\
\hline \multicolumn{5}{|l|}{ Age } \\
\hline $6-12$ months & 153 & 59 & 11.0 & \multirow{3}{*}{$3.16^{\mathrm{NS}}$} \\
\hline $13-24$ months & 255 & 93 & 17.4 & \\
\hline $25-36$ months & 128 & 37 & 6.9 & \\
\hline \multicolumn{5}{|l|}{ Sex } \\
\hline Male & 285 & 95 & 17.7 & \multirow{2}{*}{$0.991^{\mathrm{NS}}$} \\
\hline Female & 251 & 94 & 17.5 & \\
\hline \multicolumn{5}{|l|}{ Religion } \\
\hline Hindu & 473 & 155 & 28.9 & \multirow{3}{*}{$10.2^{* *}$} \\
\hline Muslim & 61 & 33 & 6.2 & \\
\hline Christian & 2 & 1 & 0.2 & \\
\hline \multicolumn{5}{|l|}{ Birth Order } \\
\hline First & 268 & 89 & 16.6 & \multirow{6}{*}{$4.96^{\mathrm{NS}}$} \\
\hline Second & 194 & 66 & 12.3 & \\
\hline Third & 54 & 24 & 4.5 & \\
\hline Fourth & 15 & 7 & 1.3 & \\
\hline Fifth & 2 & 1 & 0.2 & \\
\hline Sixth and above & 3 & 2 & 0.4 & \\
\hline \multicolumn{5}{|l|}{ Socio economic status (SES) } \\
\hline Upper High & 11 & 1 & 0.2 & \multirow{6}{*}{$22.8^{* * *}$} \\
\hline High & 53 & 15 & 2.8 & \\
\hline Upper Middle & 200 & 57 & 10.6 & \\
\hline Lower Middle & 234 & 93 & 17.4 & \\
\hline Poor & 37 & 23 & 4.3 & \\
\hline Very Poor & 1 & 1 & 0.2 & \\
\hline \multicolumn{5}{|l|}{ Type of Family } \\
\hline Nuclear & 170 & 61 & 11.4 & \multirow{3}{*}{$1.01^{\mathrm{NS}}$} \\
\hline Joint & 193 & 63 & 11.8 & \\
\hline Extended & 173 & 65 & 12.1 & \\
\hline \multicolumn{5}{|l|}{ Age of Mother } \\
\hline $18-20$ & 17 & 10 & 1.9 & \multirow{5}{*}{$5.13^{\mathrm{NS}}$} \\
\hline $21-25$ & 283 & 109 & 20.3 & \\
\hline $26-30$ & 145 & 29 & 5.4 & \\
\hline 31 and above & 37 & 12 & 2.2 & \\
\hline Don’t Know & 54 & 29 & 5.4 & \\
\hline \multicolumn{5}{|l|}{ Age of Father } \\
\hline $18-20$ & 3 & 1 & 0.2 & \multirow{5}{*}{$19.0^{* *}$} \\
\hline $21-25$ & 72 & 34 & 6.3 & \\
\hline $26-30$ & 191 & 69 & 12.9 & \\
\hline 31 and above & 214 & 56 & 10.4 & \\
\hline $\begin{array}{l}\text { Don't Know ( } 3 \text { fathers who were dead are included } \\
\text { in this category) }\end{array}$ & 56 & 29 & 5.4 & \\
\hline \multicolumn{5}{|l|}{ Educational qualification of mother } \\
\hline Illiterate & 84 & 35 & 6.5 & \multirow{3}{*}{$4.2^{\mathrm{NS}}$} \\
\hline Primary to Higher secondary (Grade 1 to 10 ) & 126 & 50 & 9.3 & \\
\hline Higher senior secondary (Grade 11 and above) & 326 & 104 & 19.4 & \\
\hline \multicolumn{5}{|l|}{ Educational qualification of father (OUT OF 533) } \\
\hline Illiterate & 37 & 17 & 3.2 & \multirow{3}{*}{$1.97^{\mathrm{NS}}$} \\
\hline Primary to Higher secondary (Grade 1 to 10 ) & 135 & 48 & 9.0 & \\
\hline Higher senior secondary (Grade 11 and above) & 361 & 124 & 23.1 & \\
\hline
\end{tabular}

Only 11 out of 536 families belonged to the upper high SES group with majority of families (234; $43.7 \%$ ) belonging to lower middle group. Upper middle income group had 200 families and 37 families were categorized in poor income group.

Almost an equal distribution was observed in the family composition with $170(31.7 \%)$ nuclear families, 193 (36.0\%) joint and 173 (32.3\%) extended families. Almost 75\% (400) families were non vegetarians. 
The average age of the mothers was 25 yrs and that of fathers was 30 yrs. About $10 \%$ mothers didn't know their age or their husband's age. Majority of the parents were literate with only $15.7 \%(84)$ mothers and $6.9 \%$ (37) illiterate fathers. Most of the mothers, $(505 ; 94.25 \%)$ were houses wives.

\section{Household information of the families}

More than half the families, 60.6\% (325) resided in semi pakka houses and open drainage system was found in $64.4 \%$ (345) households (Table 2). Hand pump or borehole was the main source of drinking water for majority $(257 ; 47.9 \%)$ of the families. Only 11 households used open well water for drinking purposes (Table 2).

Table 2. Household information of the family

\begin{tabular}{|c|c|c|c|c|}
\hline & Total & No. & $\%$ & Chi Square Value \\
\hline \multicolumn{5}{|l|}{ Drainage facility } \\
\hline Open & 345 & 132 & 24.6 & \multirow[t]{2}{*}{$3.82^{*}$} \\
\hline Close & 191 & 57 & 10.6 & \\
\hline \multicolumn{5}{|l|}{ Type of House } \\
\hline Kaccha $€$ & 62 & 27 & 5.0 & \multirow{3}{*}{$10.5^{* *}$} \\
\hline Semi Pakka £ & 325 & 125 & 23.3 & \\
\hline Pakka & 149 & 37 & 6.9 & \\
\hline \multicolumn{5}{|l|}{ Source of drinking water } \\
\hline piped water/ municipal supply & 83 & 37 & 6.9 & \multirow{4}{*}{$6.61^{\mathrm{NS}}$} \\
\hline Open well & 6 & 3 & 0.6 & \\
\hline Hand pump/ Borehole & 257 & 93 & 17.4 & \\
\hline Bottled water & 190 & 56 & 10.4 & \\
\hline \multicolumn{5}{|l|}{ Source of cooking water } \\
\hline piped water/ municipal supply & 118 & 54 & 10.1 & \multirow{4}{*}{$8.92^{*}$} \\
\hline Open well & 11 & 3 & 0.6 & \\
\hline Handpump/ Borehole & 348 & 117 & 21.8 & \\
\hline Bottled water & 59 & 15 & 2.8 & \\
\hline \multicolumn{5}{|c|}{ Source of water for other household activities } \\
\hline Piped water/ municipal supply & 164 & 69 & 12.9 & \multirow[t]{2}{*}{$4.80^{*}$} \\
\hline Handpump/ Borehole & 372 & 120 & 22.4 & \\
\hline
\end{tabular}

$€$ : house with temporary roof and walls, made of materials like wood, tin sheets, hay, asbestos etc.

$£$ : House with concrete walls but temporary roof.

$¥$ : house with concrete roof and walls.

\section{Morbidity profile of the children}

As reported by mothers, 69\% (370) children suffered from cough and cold, and 35.3\% (189) from diarrhoea in the past one month. Majority of the diarrhoeal cases $(171 ; 90.5 \%)$ were watery diarrhoea, $9.5 \%$ (18) bloody diarrhoea and 10 children were admitted to hospital during the diarrhoeal episodes.

\section{Knowledge and practices of mothers on hygiene and sanitation.}

Table 3 summarizes the ranking of mothers according to scores obtained for different hygiene aspects.

Table 3. Ranking of the mothers for different hygiene aspects

\begin{tabular}{|c|c|c|c|c|c|c|c|c|c|c|c|c|}
\hline & \multicolumn{2}{|c|}{$\mathrm{KEH}$} & \multicolumn{2}{|c|}{ PEH } & \multicolumn{2}{|c|}{$\mathrm{KFH}$} & \multicolumn{2}{|c|}{ PFH } & \multicolumn{2}{|c|}{$\mathrm{KPH}$} & \multicolumn{2}{|c|}{$\mathrm{PPH}$} \\
\hline & No. & $\%$ & No. & $\%$ & No. & $\%$ & No. & $\%$ & No. & $\%$ & No. & $\%$ \\
\hline $\begin{array}{l}91-100 \% \\
\text { (Excellent) }\end{array}$ & 382 & 71.3 & 75 & 14.0 & 45 & 8.4 & 49 & 9.1 & 410 & 76.5 & 159 & 29.7 \\
\hline $\begin{array}{c}76-90 \% \text { (Very } \\
\text { Good) }\end{array}$ & 36 & 6.7 & 99 & 18.5 & 198 & 36.9 & 423 & 78.9 & 88 & 16.4 & 264 & 49.3 \\
\hline $61-75 \%$ (Fair) & 47 & 8.8 & 95 & 17.7 & 256 & 47.8 & 63 & 11.8 & 24 & 4.5 & 100 & 18.7 \\
\hline$\leq 60 \%$ (Poor) & 71 & 13.2 & 267 & 49.8 & 37 & 6.9 & 1 & 0.2 & 14 & 2.6 & 13 & 2.4 \\
\hline Chi square value & \multicolumn{2}{|c|}{$1.92^{\mathrm{NS}}$} & \multicolumn{2}{|c|}{$14.0^{* *}$} & \multicolumn{2}{|c|}{$5.77^{\mathrm{NS}}$} & \multicolumn{2}{|c|}{$0.595^{\mathrm{NS}}$} & \multicolumn{2}{|c|}{$5.89^{\mathrm{NS}}$} & \multicolumn{2}{|c|}{$5.89^{*}$} \\
\hline
\end{tabular}

KEH: Knowledge on environmental hygiene

PEH: Practices on environmental hygiene

KFH: Knowledge on food hygiene

PFH: Practices on food hygiene

KPH: Knowledge on personal hygiene

PPH: Practices on personal hygiene

${ }^{\text {NS: }}$ Non significant ${ }^{*}: \mathrm{p}<0.05^{* *}: \mathrm{p}<0.001 \quad{ }^{* * *}: \mathrm{p}<0.0001$ 
Environmental hygiene (EH)

Majority of mothers $(382 ; 71.3 \%)$ had excellent scores for knowledge on EH. Mothers knew that accumulated water, flies, fecal matter outside the house and mopping, sweeping; animals and flies inside the house can affect their child's health. Disposing household solid waste in open was considered desirable by almost $43 \%$ (229) mothers.

The environmental hygiene practices of the mothers were comparatively poor, with almost $50 \%$ mothers scoring $\leq 60 \%$. The most undesirable practices included open defecation by $239(44.6 \%)$ families and open collection and disposal of solid waste by $79.3 \%$ (425) and $61.4 \%$ (329) families respectively and not using any disinfectant for mopping by $61.8 \%$ (331) families.

\section{Food Hygiene (FH)}

Majority of the mothers $(256 ; 47.8 \%)$ scored fairly on food hygiene. Most of the mothers $(317$; $59 \%$ ) were unaware about the safe temperatures for heating leftover moist food for consumption and almost half the mothers didn't know about the safe duration of storage of cooked moist food stored at room temperature before consumption. A large percentage of mothers $(476 ; 88.8 \%)$ regarded "bulk washing only once" as the ideal way of washing fruits and vegetables. Many $(359 ; 67 \%)$ mothers believed that "warming" the stored moist weaning foods is sufficient before feeding the baby. Boiling water and adding chlorine was reported as a method to make water safe for drinking by 289 mothers.

High percentage of mothers $(423 ; 78.9 \%)$ were ranked as "very good" for practices on food hygiene (PFH). Desirable food hygiene practices followed by mothers included using soap for washing utensils, washing fruits and vegetables before use and air drying of utensils after washing. The most undesirable food hygiene practices included dipping a container in stored water vessel (where hand comes in contact with water) for drawing water and consuming moist leftover food without sufficient heating.

\section{Personal Hygiene (PH)}

Excellent scores were obtained by most of the mothers $(410 ; 76.5 \%)$. Almost all mothers (524; 97.8\%) knew that washing their hands and child's hands (506; 94.4\%) before feeding the child is necessary. Many knew that washing hands with soap is much better than water alone as it facilitates efficient removal of dirt and germs and helps prevent diseases. Personal hygiene practices of the mothers were assessed primarily with respect to their hand washing practices with soap. Mothers were questioned regarding use of soap for washing hands before and after a number of activities.

All the mothers used soap after visiting toilet and also after attending the child who has defecated. Every mother bathed daily and wore clean clothes. Only half used soap for washing hands before feeding the child and an almost similar number before eating food. Insufficient use of soap was found before cooking, before breastfeeding the child and after touching raw foods. The overall scores showed that only $29.7 \%(159)$ mother had excellent scores for personal hygiene practices.

\section{Association of diarrhoea with various parameters:}

Diarrhoeal diseases were highly significant with the SES, and type of house in which the families resided (Table 1-3). Other factors associated with diarrhoeal diseases included religion of the family, age of father, drainage facility, type of house, source of cooking water and water used for other household activities, practices on environmental and personal hygiene practices of the mothers. Age and sex of the child, birth order of the child and type of family were not statistically associated with the occurrence of diarrhoeal diseases along with the mother's age, parents educational qualification, mother's working status, source of drinking water, mother's knowledge on $\mathrm{EH}, \mathrm{FH}$ and $\mathrm{PH}$ and practices on $\mathrm{FH}$.

\section{DISCUSSION}

The present study is one of its kinds as no data is available from the tribal regions of Indian sub continent eliciting household hygiene practices as a causative factor of diarrhoea among young children.

Household information of the families shows that $64.4 \%$ households had open drainage system indicating poor environmental conditions. Children residing in semi pakka houses were found to have maximum number of diarrhoeal episodes in the present study.

Though majority of mothers (71.3\%) got excellent scores for KEH, almost $50 \%$ scored poorly for PEH. High percentage (44.6 and 61.4) of families practiced open defecation and open disposal of solid waste, which were the most common undesirable environmental hygiene practices followed. Similar observations were made by surveyors in a study conducted at Democratic Republic of the Congo [27] .The present study revealed that the mothers who had poor PEH scores had the maximum number of children suffering from diarrhoea. 
Environmental hygiene as a determinate of diarrhoeal diseases has been pointed out in many studies [28]-[32]. Maung [33] and Freji [34] in their studies pointed out that better family incomes is likely to translate into improvements in housing with more hygienic toilets, fewer flies in the house and ingestion of better weaning foods. According to WHO [35] majority of diarrhoeal cases are attributed to unsafe water, inadequate sanitation and hygiene. In the present study also environmental hygiene practices of the mothers were found to be associated with the occurrence of diarrhoea in the children.

In the present study handwashing practices of the mothers was found to be considerably good. All mothers were washing hands with soap after self and child defecation which is a desirable practice. Insufficient handwashing was observed before cooking and feeding the child which can be a source of contamination. In a similar study in India, Ray et al [36] pointed out that mothers were washing hands with soap after defecation but not after activities like changing babies nappies, before preparing food, immediately after handling raw vegetables and after handling pets and domestic animals. Wilson et al [37] reported a reduction in diarrhoea incidence of $89 \%$ through the promotion of hand washing in four different circumstances, including after defaecation, in an Indonesian village. Studies in Nicaragua and Salvador have shown that diarrhoeal episodes increased with poor hand washing practices [38],[39]. The study also showed statistical association of personal hygiene practices (attributed to handwashing practices) of the mothers with occurrence of diarrhoeal diseases in children. Hence an increase in the use of soap for hanwashing can help bring down the diarrhoeal episodes in children.

Diarrhoeal diseases were not associated with age and sex of the child, mothers and fathers education qualification, weight for age of the child, knowledge on $\mathrm{EH}, \mathrm{FH}, \mathrm{PH}$ and practices on $\mathrm{FH}$. These are similar to the finding of previous studies which showed maternal characteristics such as education, occupation and age had no effect on diarrhoeal incidence [40],[41].

This study has certain limitations. Firstly the hygiene practices were graded on the basis of self reported behaviours of the mothers and hence are subject to inaccuracy. Therefore further investigation is required which should use household observations. Other researchers have pointed out that variety of methods are currently utilized to capture sanitation and hygiene behaviours. Interview and questionnaire approaches, while easily modified to represent the community under study, may not be as easily standardized as other available methods and typically result in over-reporting of 'good' behaviours, thus, reducing their validity [42]-[45]. Secondly majority of the subjects in the study resided in areas where there was neither a provision of public toilets nor proper disposal of solid waste. Hence open defecation and solid waste disposal was highly practiced which contributed to low environmental hygiene practice scores.

\section{CONCLUSION}

To conclude the results of the study suggest that improvement in the environmental and personal hygiene practices of the mothers can contribute largely in reducing the prevalence of diarrhoea among children. Apart from that improvement in the civic facilities like provision for toilets and disposal of household waste will automatically contribute to improvement in environmental hygiene practices. Hence attention of the concerned needs to be drawn in this particular area.

\section{REFERENCES}

[1]. Liu L, Johnson HL, Cousens S, Perin J, Scott S, Lawn JE, Rudan I, Campbell H, Cibulskis R, Li M, Mathers C, Black RE, "Child Health Epidemiology Reference Group of WHO and UNICEF. Global, regional, and national causes of child mortality: an updated systematic analysis for 2010 with time trends since 2000", Lancet, vol/issue: 379(9832), pp. 2151-61, 2012.

[2]. Walker CLF, Perin J, Aryee MJ, Pinto CB and Black RE, "Diarrhea incidence in low- and middle-income countries in 1990 and 2010: a systematic review", BMC Public Health, vol. 12, pp. 220, 2012.

[3]. PATH, "A catalyst for global health", Diarrhoeal disease: Solutions to defeat the global killer, Washington DC, 2009.

[4]. WHO 2008, "Safe Water, better health", Geneva, 2008.

[5]. Bartram J, Cairncross S., "Hygiene, Sanitation, and Water", Forgotten Foundations of Health, vol/issue: 7(11), 2010. e1000367. PLoS Medicine.

[6]. Karambu S; Matiru V; Kiptoo M; Oundo J., "Characterization and factors associated with diarrhoeal diseases caused by enteric bacterial pathogens among children aged five years and below attending Igembe District Hospital", Kenya.Pan African Medical Journal, vol. 16, pp. 37, 2013. doi:10.11604/pamj.2013.16.37.2947.

[7]. Curtis V; Cairncross S; Yonil R., "Review: Domestic hygiene and diarrhoea - pinpointing the problem", Trop Med Internat Health, vol/issue: 5(1), pp 22-32, 2000.

[8]. Elaine L and Allison E., "Hygiene and Health: An epidemiologic link?", Am J Infect Control, vol. 29, pp. 232-8, 2001. 
[9]. Emina JBO, Kandala N-B., "Accounting for recent trends in the prevalence of diarrhoea in the Democratic Republic of Congo (DRC): results from consecutive cross-sectional surveys", BMJ Open, vol. 2, 2012. e001930. doi:10.1136/bmjopen-2012-001930.

[10]. Agustina R, Sari TP, Satroamidjojo S, Oudenhoven IMJb., Feskens EJM and Kok FJ., "Association of foodhygiene practices and diarrhea prevalence among Indonesian young children from low socioeconomic urban areas", BMC Public Health, vol. 13, pp. 977, 2013.

[11]. http://www.who.int/water_sanitation health/monitoring/oms brochure core questionsfinal24608.pdf

[12]. http://pdf.usaid.gov/pdf_docs/PNADF300.pdf

[13]. http://www.unicef.org/oPt/FINAL_WASH_REPORT.pdf.

[14]. http://navsaridp.gujarat.gov.in/navsari/english/chikli-taluka.htm.

[15]. http://navsaridp.gujarat.gov.in/navsari/taluka/chikhali/index.htm.

[16]. http://www.onefivenine.com/india/villag/Navsari/Chikhali.

[17]. Aggarwal OP, Bhasin SK, Sharma AK, Chhabra P, Aggarwa K, Rajoura OP., "A New Instrument (Scale) for Measuring the Socioeconomic Status of a Family: Preliminary Study", Ind J Comm Med, vol/issue: 30(4), 2005.

[18]. www.zpjalgaon.gov.in/pdf/VillagePanchayat/TSC/baselinesurvey.pdf.

[19]. http://www.measuredhs.com/pubs/pdf/FRIND3/FRIND3-VOL2.pdf

[20]. http://www.arghyam.org/sites/default/files/Ashwas\%20Process\%20Handbook\%20-\%20pdf\%20version.pdf

[21]. http://sangamindia.org/uploads/MGRSurvey.pdf

[22]. http://www.who.int/water_sanitation_health/monitoring/oms_brochure_core_questionsfinal24608.pdf

[23]. http://pdf.usaid.gov/pdf_docs/PNADF300.pdf

[24]. http://www.unicef.org/oPt/FINAL_WASH_REPORT.pdf.

[25]. Nielsen M, Hoogvorst A, Konradsen F, Mudasser M, van der Hoek W., "Causes of childhood diarrhea as perceived by mothers in the Punjab, Pakistan”, Southeast Asian J Trop Med Public Health, vol/issue: 34(2), pp. 343-51, 2003.

[26]. Takanashi K, Chonan Y, Quyen D T, Khan NC , Poudel KC, and Jimba M., "Survey of Food-hygiene Practices at Home and Childhood Diarrhoea in Hanoi, Viet Nam", J Health Popul Nutr, vol/issue: 27(5), pp. 602-611, 2009.

[27]. MDF Afrique Centrale, "Baseline Survey Water, Sanitation and Hygiene", Nyiragongo Territory, North Kivu Province Democratic Republic of the Congo (DRC), October 2008.

[28]. Strina A, Cairncross S, Barreto ML, Larrea C, Prado MS., "Childhood Diarrhea and Observed Hygiene Behavior in Salvador", Brazil Am J Epidemiol, vol. 157, pp. 1032-1038, 2003.

[29]. Shamebo, D., Sandstrom, A. Muhe, L., "The Butajira project in Ethiopia: A nested case-referent study of underfive mortality and its public health determinants", Bull. WHO, vol. 71, pp. 389-396, 1993.

[30]. Kolsky PJ., "Water, sanitation and diarrhoea: limits of understanding", Trans. Roy. Soc. Trop. Med. Hyg., vol. 87, pp 43-46, 1993.

[31]. D.L. Daniels D.L., Cousens SN, Makoae LN, Feachem RG., "A case-control study of the impact of improved sanitation on diarrhoea morbidity in Lesotho", Bull WHO, vol/issue: 66(4), pp. 455-463, 1990.

[32]. UNICEF, "Palestinian Hydrology Group. Water, Sanitation and Hygiene Household Survey Gaza", April 2010.

[33]. Maung KU, Khin M, Wai NN, Hman NW, Myint TT, Butler T., "Risk factors for the development of persistent diarrhoea and malnutrition in Burmese children", Int J Epid, vol/issue: 21(5), pp. 1021-1021, 1992.

[34]. Freij, L., and Walls, S., "Exploring Child Health and its ecology", The Kirkos study in Addis Abatia. Acta Paed. Scand., vol/issue: 267(1), pp. 1-120, 1997.

[35]. WHO, "Combating waterborne disease at the household level, The International Network to Promote Household Water Treatment and Safe Storage", WHO Document Production Services, Geneva, Switzerland 2007.

[36]. Ray SK; Zaman FA and Laskar NB., "Handwashing practices in two communities in two states of Eastern India", An Intervention Study, Ind J Pub. Health, vol/issue: 54(3), 2010.

[37]. Wilson JM, Chandler GN, Muslihatun, Jamiluddin, "Hand washing reduces diarrhoea episodes: a study in Lombok, Indonesia", Roy. Soc. Trop. Med. Hyg, vol. 85, pp. 819-821, 1991.

[38]. Gorter AC, Sandiford P, Pauw J, Morales P, Perez RM, Alberts H., "Hygiene behavior in rural Nicaracgua in relation to diarrhea", Int J Epi, vol. 27, pp. 1090-1100, 1998.

[39]. Strina A, Cairncross S, Barreto ML, Larrea C, and Prado MS., "Childhood diarrhoea and observed hygiene behaviour in Salvador, Brazil”, A J Epi, vol/issue: 157(11), 2003.

[40]. Marouz YY, Aziz KMS, Khalil M., "Association of parents education and fathers occupation with prevalence of diarrhoea among children less than five years of age in Saudi Arabia”, J. diarrhoeal Dis. Res, vol. 9, pp. 301-304, 1991.

[41]. Moy JP, Booth IW, Choto R, McNeish AS., "Risk factors for high diarrhoeal frequency: a study in rural Zimbabwe", Trans. Roy. Soc. Trop. Med. Hyg., vol. 85, pp. 814-818, 1991.

[42]. Curtis V, Cousens S, Mertens T et al., "Structured observations of hygiene behaviours in Burkina Faso: validity, variability, and utility", Bull WHO, vol. 71, pp. 23-32, 1993.

[43]. Manun'ebo MN, Cousens S, Haggerty PA et al., "Measuring hygiene practices: a comparison of questionnaires with direct observations in rural Zaire", Trop Med Int Health, vol. 2, pp. 1015-21, 1997.

[44]. Odujinrin OM, Akitoye CO, Odugbemi T, Oyerinde JP, Esumeh FI., "Ethnographic study on childhood diarrhoeal diseases in a rural Nigerian community", West Afr J Med, vol. 12, pp. 185-88, 1993.

[45]. Stanton BF, Clemens JD, Aziz KMA, Rahman M., "Twenty-four hour recall, knowledge-attitude-practice questionnaires, and direct observations of hygiene behaviors in Burkina Faso: validity, variability, and utility", Bull WHO, vol. 65, pp. 217-22, 1987. 